\title{
General Equilibrium Impacts of VAT and Corporate Income Tax in Thailand
}

\section{Chonlakan Benjasak $^{1} \cdot \operatorname{Keshab}_{\text {Bhattarai }^{1}}$ (D)}

Published online: 9 August 2019

(C) The Author(s) 2019

\begin{abstract}
In this paper, a computable general equilibrium model of Thailand is constructed in order to assess economy-wide impacts of reforms in the value added tax (VAT) and corporate income tax (CIT) on welfare and reallocation of resources across production sectors in the Thai economy. The model was calibrated to the micro-consistent benchmark data set contained in the InputOutput Table 2010 published by the Office of National Economics and Social Development Board with restructuring into 18 sectors. Findings reveal that aggregate net changes in welfare from a $10 \%$ VAT rate are better than from a $0 \%$ VAT. Thus, increasing VAT from 7 to $10 \%$ is a desirable policy action on the basis of economy-wide welfare analysis because utility generated from public services for the households more than compensates their loss in utility due to higher taxes. On a net welfare basis, decreasing the CIT rate from 30 to $20 \%$ is more preferable policy than reducing it to $23 \%$. This model-based analysis is a unique contribution to the current literature on impacts of VAT and CIT in the Thai economy. Further scope remains for full impact analysis of comprehensive reforms such as the goods and services tax, with a dynamic model and many households.
\end{abstract}

Keywords Tax policy $\cdot$ VAT $\cdot$ Corporate income tax $\cdot$ Thailand's CGE model

JEL Classification $\mathrm{E} 62 \cdot \mathrm{O} 52$

Electronic supplementary material The online version of this article (https://doi.org/10.1007/s11294-01909742-7) contains supplementary material, which is available to authorized users.

Keshab Bhattarai

K.R.Bhattarai@hull.ac.uk

1 Faculty of Business, Law and Politics, University of Hull, Hull HU6 7 RX, UK 


\section{Introduction}

Fiscal policy, which includes both government spending and taxation, is one of the key instruments that the government uses to achieve stability and growth in an economy. The Thai Government derives revenue predominantly from taxes, the most important of which include income tax, value-added tax, excise tax, and import duties (Sujjapongse 2005). Vulnerability in the world economy and economic potentials in Thailand motivated the Thai government to embark on an ambitious reform programs to raise long-term growth and achieve high-income status. However, these reform programs cannot be realised if the government decreases expenditures. Tax revenue is the most significant source of government income. Therefore, changes in tax revenue will affect government spending and also the whole economy. Tax reform occurs by changes in tax administration, the tax base, or tax rates.

Many empirical studies have tried to examine the impact of tax reform on an economy. For instance, Lee and Gordon (2005) employed cross-country data to examine how tax policies affected 70 countries' growth rates during 1970-1997. Onwuchekwa and Aruwa (2014) used ordinary least squares techniques to explore the impact of the value-added tax (VAT) on Nigeria's economy. Other papers that explained the association between taxes and economic growth include $\mathrm{McNabb}$ and LeMay-Boucher (2014), Arnold et al. (2011), Barrell and Weale (2009), and Blundell (2009). However, these works failed to analyse the full impact of taxation policy, as they only applied partial equilibrium approaches. Therefore, a gap exists for a more comprehensive approach that can explain the interrelationships among all agents in the economy who are affected by tax policy changes.

Researchers have tried to fill the gap in the literature by applying general equilibrium theory to analyse the impact of tax, other policies and other external shocks on all sectors of the economy. For example, Amir et al. (2013) used the computable general equilibrium (CGE) model to explain how, for Indonesia, reductions in personal income tax (PIT) and corporate income tax (CIT) increased economic growth and income inequality. The findings revealed that under both a balanced budget and non-balanced budget, the reduction in PIT and CIT reduced the poverty level in Indonesia, but the CIT policy had no impact on income inequality. For sectoral impacts, the reduction in PIT and CIT under a balanced budget assumption led to a decline in price in all sectors, whereas the outputs in all sectors increased, except in the government administration sector. Under the non-balanced budget scenario, the reduction in PIT and CIT increased the prices in all sectors while the output in some sectors decreased. Bhattarai (2007) used the CGE approach to forecast the impact of tax distortion on the level of capital accumulation and welfare across households in the Hull and Humber Region. His findings were consistent with his later work (Bhattarai 2011). A higher rate of energy and environmental taxes can slow down the growth rates of output across all sectors and reduce the level of household welfare. Other studies that applied the CGE model to analyse the impact of environmental taxation policies on the economy include Al-Amin et al. (2008) and Bergman (1990).

For Thailand, some previous studies applied CGE models for policy analyses. Puttanapong et al. (2015) used this technique to study the impact of carbon-tax policies on the Thai economy. Winyuchakrit et al. (2011) developed a CGE model to analyse the possibility of Thailand becoming a low-carbon society. Wianwiwat and Asafu- 
Adjaye (2013) used a static CGE model to investigate the impact of biofuel-promoting measures contained in the Thai government's 10-year alternative energy development plan. Additionally, Field and Wongwatanasin (2007) applied a CGE model to assess the effects of alternative tax and transfer policies on output, trade flows and income distribution for specific industries and for the Thai economy as a whole.

Although those previous studies explain some economy-wide impacts of tax policies, there is no specific analysis on the impact of VAT and CIT on the Thai economy. This study aims to fill this gap in the literature. The main objective is to construct a CGE model of the Thai economy in order to assess the impact of changes in fiscal policy, especially tax policies, on the economy. This model contributes to the existing studies as it evaluates the economy-wide income and substitution effects and how they impact the growth of the Thai economy resulting from changes in VAT and CIT rates, on output, prices, welfare and sectoral allocation of capital and labour inputs in production. Such an analysis is important as the VAT and CIT are the first and second largest sources of government revenue in Thailand. No systematic study exists, to our knowledge, that assesses the impact of reforms in these taxes in Thailand.

\section{Overview of Taxation in Thailand}

The Ministry of Finance is authorized to collect taxes through the Department of Revenue, the Department of Excise, and the Department of Customs. The Department of Revenue is in charge of collecting taxes based on income and domestic consumption as provided under the Revenue Code and related laws on personal income tax, CIT, petroleum income tax, VAT, stamp duties and the bird's nest concession. The Department of Excise collects taxes from 11 types of domestic and import goods and services, namely, spirits, tobacco, playing cards, beverages, electrical lamps and air conditioners, crystal ware and glasses, petroleum products, passenger cars, yachts and luxury boats, perfumes, and race courses. Last, the Department of Customs raises revenue from import and export tariffs. Furthermore, other departments in other ministries are empowered to levy other related charges or fees. For example, the Department of Land collects registration fees on the transfer of land ownership. Other revenue sources are profit remittances from state enterprises, privatization, and income of government properties. Among the aforementioned departments, the biggest source of government revenue in 1992 and 2015 came from the Revenue Department which accounted for $49 \%$ and $65 \%$ of total revenue, respectively. In terms of tax types, the biggest source of tax revenue collected by the Revenue Department in 1992 and 2015 was VAT which accounted for $35 \%$ and $41 \%$, respectively, followed by CIT, personal income tax, petroleum tax, specific business tax, stamp duty and other taxes (Fiscal Information 2016).

The VAT in Thailand was introduced on January 1, 1992 to replace the business tax (Sujjapongse 2005). At that time, the Thai economy was in a rapid growth phase led by a reform in its fiscal and financial sectors. The Thai government applied the VAT on sales at the $10 \%$ rate. However, in 1997 there was a financial crisis in Thailand and the Thai 
Table 1 Value-added tax and corporate income tax rate adjustment in Thailand and some ASEAN countries

\begin{tabular}{llllll}
\hline & \multicolumn{2}{l}{ VAT or GST (\%) } & & \multicolumn{2}{l}{ Corporate income tax (\%) } \\
\cline { 2 - 3 } \cline { 5 - 6 } \cline { 5 - 6 } & Old rate (in 1992) & Current rate (in 2017) & & Old rate (in 2009) & Current rate (in 2017) \\
\hline Thailand & 10 & 7 & 30 & 20 \\
Singapore & $3^{\mathrm{a}}$ & 7 & 18 & 17 \\
Malaysia & $6^{\mathrm{a}}$ & 6 & 25 & 24 \\
Vietnam & $10^{\mathrm{a}}$ & 10 & 25 & 20 \\
ASEAN average & $8.6^{\mathrm{b}}$ & $9^{\mathrm{b}}$ & $26^{\mathrm{c}}$ & $22.17^{\mathrm{c}}$ \\
\hline
\end{tabular}

Sources: KPMG (2017), Avalara Vatlive (2016) and Mok (2017)

a denotes initial VAT or GST rates implemented in Singapore, Malaysia and Vietnam in 1993, 2015, and 1999, respectively

${ }^{\mathrm{b}}$ denotes ASEAN average VAT or GST rate in eight ASEAN countries, excluding Myanmar and Brunei

${ }^{c}$ denotes ASEAN average CIT rate in nine ASEAN countries, excluding Laos due to data limitations

economy was in a weak situation. Thus, the Thai government reduced the VAT from $10 \%$ to the current level of $7 \%$ on April 1, 1999 in order to stimulate the economy. It was a temporary measure that was expected to expire in two years, but the government decided to extend it until 30 September 2017. The Thai cabinet decided to extend VAT at $7 \%$ until 30 September 2019 (Bangkok Post 2018) in order to maintain the people's purchasing power and build public confidence in the Thai economic growth. Despite that, the National Legislative Assembly proposed that the cabinet raise VAT to $8 \%$ believing that it would boost government revenue by up to 70 billion Baht a year. This is consistent with the study of Sujjapongse (2005) who revealed that a $1 \%$ increase in VAT resulted in 30 billion Baht in additional government revenue, though it might cause a $0.95 \%$ reduction in the GDP growth rate. Table 1 depicts the VAT rate in Thailand, which is the same as the goods and services tax (GST) rate in Singapore but still lower than the ASEAN average rate $(9 \%)$.

Apart from VAT, the second largest source of government revenue in Thailand is CIT. It is a direct tax imposed on a juristic company ${ }^{1}$ or partnership either carrying on business in Thailand or deriving certain types of income from Thailand. In 2009, the CIT rate in Thailand was $30 \%$ on net profit which was relatively high compared to those in Association of Southeast Asian Nations (ASEAN) countries (Table 1). In 2012, the Thai government lowered the CIT rate to $23 \%$ and to $20 \%$ in 2013 . The purpose of these reductions was not only to lower the cost of Thai firms but also to increase their competitiveness in the world market. At first, the government applied the CIT rate at $20 \%$ until the end of 2015 and planned to employ a $30 \%$ rate after that. However, Jatusripitak in Dailynews (2015) announced that the Thai government decided to retain the CIT at the $20 \%$ rate on net profit permanently. Although this policy will reduce the government revenue by Baht 179,000 million annually, it will not affect foreign investment and will also benefit Thai companies. Furthermore,

\footnotetext{
${ }^{1}$ A juristic company under Thai law consists of limited company, public company limited, limited partnership and registered partnership (The Revenue Department 2018).
} 
the reduction in the CIT rate is consistent with policies in other neighbouring countries such as Malaysia (24\%) and Vietnam (20\%).

\section{Model Structure}

A general equilibrium model illustrates how an adjustment in the system of relative prices balances supply and demand across various markets in an economy. This theory explains the mechanism by which the choices of economic agents are coordinated across all markets.

The general equilibrium model in this study builds on Bhattarai (2008). Modifications were made to capture the characteristic of the Thai economy. The model includes a representative household, 18 producers, a government sector and the rest of the world. A representative household supplies capital and labour in factor markets and acts as a consumer who aims to maximize utility under a budget constraint. The production side is more decentralised in the model. The main purpose for each of these producers is to maximise profit (or minimise cost) conditional on competitive markets with constant elasticity of substitution (CES) or Cobb-Douglas type production technologies. They produce under constant return to scale conditions. The government collects revenue from various taxes and uses that revenue to provide public services.

In this model there is a nested function for consumption, production and trade, in common with many CGE models. Capital and labour inputs were used to generate value added. Intermediate input was combined with value added by a Leontief production technology. In each tradable sector, gross domestic supply is either sold in the domestic market or exported to the rest of the world according to a constant elasticity of transformation function. The total supply of goods in tradable sectors of the economy is a CES composite of differentiated domestic and imported Armington commodities. Details on the model are in the Online Supplemental Appendix Table 1.

\section{Description of Data}

This model uses the latest economic data from the 180 sector Input-Output Table from 2010 obtained from the National Economics and Social Development Board (2016) to construct micro-consistent data for Thailand. These data were restructured into 18 production sectors namely the: (1) agriculture sector (2) mining and quarrying sector (3) food manufacturing sector (4) textile industry sector (5) saw mills and wood products sector (6) paper industries and printing sector (7) rubber and chemical industries sector (8) non-metallic products sector (9) metal, metal products and machinery sector (10) other manufacturing and unclassified sector (11) construction sector (12) trade and services sector (13) transportation and communication sector (14) coal and lignite sector (15) petroleum and natural gas sector (16) petroleum refineries sector (17) other petroleum product sector and (18) electricity sector (Online Supplemental Appendix Table 2). These data were used for calibrating the model parameters. The general algebraic modelling system (GAMS 2017) was applied to compute the model for evaluating changes in the economy or to assess the impact of alternative tax policies (Bergman 1990; Semboja 1994; Bhattarai 2007, 2016, 2017; Ruamsuke et al. 2015). 
The original data were not perfect as some of the accounts were not balanced. Labour and capital in each sector were modified adding 300 and 200, respectively, to balance the account and avoid a situation where the tax rates could exceed $100 \%$. That modification was enough to remove the imbalance in demand and supply and to reach an optimal solution to the model.

Table 2 depicts the benchmark dataset for this study. The trade and services sector were the largest users of labour and capital which accounted for $24 \%$ and $29 \%$ of total labour and capital, respectively. These were followed by the agriculture sector, metal, metal products and machinery sector, transportation and communication sectors, and food manufacturing sector. For energy sectors, labour accounted for the highest level in electricity sector, while the petroleum and natural gas sector was capital intensive. At the same time, the coal sector used the least amount of labour and capital input. In this benchmark case, the VAT equaled $7 \%$ across all sectors.

In the general equilibrium model, the elasticity parameters, which represent the flexibility of markets, played very crucial role in determining model results. They influenced the magnitude of welfare changes and the marginal excess burden of

Table 2 Tax Rates and Output in Thailand, 2010: Benchmark Dataset by Sectors

\begin{tabular}{|c|c|c|c|c|c|c|c|c|}
\hline & \multicolumn{2}{|c|}{ Factor inputs } & \multicolumn{2}{|c|}{ Capital tax revenues } & \multicolumn{3}{|c|}{ Factor Inputs, Tax Rates } & \multirow[b]{2}{*}{ Output } \\
\hline & Labour & Capital & Ktax & Import & K_tax & Ltax & VAT & \\
\hline Agric & 610.363 & 957.903 & -493.029 & 605.348 & -0.468 & -0.017 & 0.070 & 1787.359 \\
\hline Mining & 310.887 & 224.329 & 11.758 & 220.231 & 0.070 & 0.004 & 0.070 & 301.623 \\
\hline FoodManu & 444.956 & 488.742 & -36.499 & 410.086 & 0.034 & 0.113 & 0.070 & 2381.237 \\
\hline Textile & 373.989 & 302.877 & -28.446 & 149.343 & 0.017 & 0.032 & 0.070 & 771.757 \\
\hline SawMill & 325.655 & 236.599 & 9.211 & 18.301 & 0.076 & 0.009 & 0.070 & 199.232 \\
\hline Paper & 321.402 & 239.188 & -44.470 & 124.547 & -0.142 & 0.012 & 0.070 & 256.167 \\
\hline Rubber & 421.392 & 403.069 & -41.723 & 457.122 & 0.047 & 0.057 & 0.070 & 1578.832 \\
\hline NonMetal & 333.343 & 257.593 & -2.921 & 51.127 & 0.078 & 0.019 & 0.070 & 399.582 \\
\hline Metal & 591.218 & 764.760 & -605.041 & 2834.137 & -0.551 & 0.241 & 0.070 & 5875.675 \\
\hline OthManu & 412.092 & 336.224 & 62.147 & 324.392 & 0.348 & 0.053 & 0.070 & 1323.773 \\
\hline Const & 367.580 & 286.724 & 30.118 & 150.000 & 0.257 & 0.027 & 0.070 & 915.144 \\
\hline Trade & 2153.481 & 2543.785 & -1948.928 & 1977.208 & -0.496 & 0.154 & 0.070 & 7433.842 \\
\hline Trans & 520.995 & 454.953 & -158.388 & 65.532 & 0.270 & 0.060 & 0.070 & 1681.562 \\
\hline Coal & 302.722 & 207.705 & -2.987 & 3.151 & -0.012 & 0.001 & 0.070 & 17.421 \\
\hline Petro & 377.390 & 321.559 & -163.313 & -61.434 & -0.249 & 0.127 & 0.070 & 560.217 \\
\hline PetroRefin & 312.124 & 225.043 & 7.209 & 1028.813 & 0.099 & 0.017 & 0.070 & 1210.326 \\
\hline OthPetro & 312.122 & 222.240 & -7.738 & 50.264 & -0.005 & 0.020 & 0.070 & 115.311 \\
\hline Electri & 406.382 & 290.878 & 7.097 & 139.584 & 0.302 & 0.027 & 0.070 & 705.733 \\
\hline
\end{tabular}

Source: Own calculations for the CGE model of Thailand using data from the National Economics and Social Development Board (2016)

Ktax is the total tax revenue from inputs including depreciation. $\mathrm{K}_{-}$tax represents tax rates on capital. Ltax is tax rates on labour income 
taxes across model scenarios. The values of elasticity used in this model were based on generally accepted values in the literature. In addition to information on the benchmark dataset and elasticity parameters, this model also adjusted quantities such that the benchmark price was one for goods as well as for labour and capital inputs.

\section{Analysis of Model Results}

As aforementioned, the main objective in this paper was to evaluate the impact of reforms in the overall and sectoral tax structure in the Thai economy. At the macro level, the focus was on reforms to the VAT and CIT, as well as variations in taxes in the energy sector.

Six scenarios were considered to assess impacts of taxes in this study. These include the: (i) baseline case when the VAT is 7\%; (ii) impact of the increase in the VAT from 7 to $10 \%$ and the change in the capital tax rate in the food manufacturing and petroleum refineries sectors to 10\%; (iii) impact of the decrease in VAT to $0 \%$ and setting the capital tax rate in petroleum refineries to $0 \%$; (iv) baseline case when the CIT rate was $30 \%$; (v) impact of a decrease in the CIT rate from 30 to $23 \%$; and (vi) impact of a decrease in the CIT rate from 30 to $20 \%$.

Table 3 Percentage Change in Macroeconomic Variables of Increasing the VAT from 7 to 10 Percent

\begin{tabular}{|c|c|c|c|c|c|c|}
\hline & Labour & Capital & Output & Supply & Price & Rental \\
\hline Agric & -3.3400 & -3.2000 & -3.2800 & -3.2800 & 1.1700 & -0.4000 \\
\hline Mining & 2.4100 & 2.5700 & 2.4900 & 2.4900 & 1.2700 & -0.4000 \\
\hline FoodManu & -3.3800 & -3.2400 & -3.4400 & -3.4400 & 1.0200 & -0.4000 \\
\hline Textile & 1.2200 & 1.3700 & 1.2900 & 1.2900 & -1.7700 & -0.4000 \\
\hline SawMill & -0.1000 & 0.0400 & -0.0400 & -0.0400 & -0.6100 & -0.4000 \\
\hline Paper & 2.5300 & 2.6800 & 2.5900 & 2.5900 & 0.3000 & -0.4000 \\
\hline Rubber & 1.0200 & 1.1700 & 1.0900 & 1.0900 & -2.3200 & -0.4000 \\
\hline NonMetal & -0.2600 & -0.1200 & -0.2000 & -0.2000 & -0.2000 & -0.4000 \\
\hline Metal & -0.4200 & -0.2700 & -0.3700 & -0.3700 & 0.3000 & -0.4000 \\
\hline OthManu & 1.8700 & 2.0200 & 1.9500 & 1.9500 & -1.8800 & -0.4000 \\
\hline Const & 0.1000 & 0.2500 & 0.1700 & 0.1700 & 0.5000 & -0.4000 \\
\hline Trade & 1.2800 & 1.4300 & 1.3400 & 1.3400 & 0.8900 & -0.4000 \\
\hline Trans & 0.3400 & 0.4900 & 0.4200 & 0.4200 & -1.0200 & -0.4000 \\
\hline Coal & -0.1900 & -0.0300 & -0.1300 & -0.1200 & -0.3000 & -0.4000 \\
\hline Petro & -0.1800 & -0.0300 & -0.1300 & -0.1300 & -1.1300 & -0.4000 \\
\hline PetroRefin & -1.6900 & -1.5500 & -1.6300 & -1.6300 & 2.9100 & -0.4000 \\
\hline OthPetro & 0.2500 & 0.4000 & 0.3100 & 0.3100 & -0.2000 & -0.4000 \\
\hline Electri & -0.1200 & 0.0300 & -0.0500 & -0.0500 & 0.5000 & -0.4000 \\
\hline
\end{tabular}

Source: Own calculations based on the CGE model of Thailand using data from the National Economics and Social Development Board (2016) 
In the benchmark case when VAT equals $7 \%$, the simulation results showed that trade and services was a predominant sector with the highest level of labour, capital, output, and supply. The mining and quarrying sector had the smallest values of labour, capital, output, and supply. Consequently, output in this sector had the highest price (Online Supplemental Appendix Table 3).

Among energy sectors, the electricity sector had the highest level of labour and output while the coal and lignite sector had the smallest labour, capital, output, and supply. In terms of price, the petroleum refineries sector had the highest price, followed by the electricity sector.

The increase in the VAT rate from 7 to $10 \%$ led to a significant change in all macroeconomic variables (Table 3 ). This policy benefited the producers and consumers in the textile industry sector, the rubber and chemical industries sector, the other manufacturing and unclassified sector, and the transportation and communication sector. When the producers in these sectors increased their production and use of labour and capital inputs, consumers benefited from the reduction of prices in these sectors. On the other hand, this policy had adverse effects on the agriculture sector, food manufacturing sector, and metal, metal products and machinery sector because the producers reduced the use of labour and capital. Consequently, the prices of these products increased in response to the reduction in outputs. In contrast, an increase in the price of the mining and quarrying sector, paper industries and printing sector, trade and services sector, and construction sector stimulated the production, employment, and the use of capital in these sectors.

For the energy sectors, employment, capital, output, and supply declined in the coal and lignite sectors with the same magnitude as the petroleum and natural gas sectors. In addition, prices in the petroleum and natural gas sector decreased more than prices in the coal and lignite sector. The same amount of decrease $(1.63 \%)$ was observed in the output and supply value in the petroleum refineries sector which reflected the biggest influence from VAT policy. Subsequently, the price of petroleum refineries products increased and might have led to a decrease in demand for this product due to the reduced labour and capital use. For the electricity sector, even though there were moderate decreases in output and supply, there was a substitution effect from labour to capital. In contrast, the other petroleum product sector was the only energy sector where labour, capital, output and supply increased from the change in the VAT rate from 7 to $10 \%$. Consequently, the price of this sector declined by only $0.2 \%$.

Furthermore, there was a decrease in rental rates $(0.4 \%)$ in all sectors as VAT raised the cost of production. This is consistent with the assumption that the price of capital was the same in all sectors of the economy.

From these results, one can conclude that the increase in the VAT rate from 7 to $10 \%$ led to an increase in prices and a decrease in outputs in the agriculture and food manufacturing sectors, which are necessary products for every economic agent. Similarly, an increase in the cost of petroleum refineries and electricity sectors led to a decline in the outputs of these sectors. These results are intuitively correct.

There were significant changes in many sectors when the VAT rate was set to $0 \%$ in comparison to $7 \%$ in the benchmark (Table 4). Interestingly, this policy had favourable effects on consumers who were able to buy agricultural products, mining and quarrying products, and metal, metal products and machinery products at lower prices. 
Table 4 Percentage Change in Macroeconomic Variables of Reducing VAT from 7 to 0 Percent

\begin{tabular}{|c|c|c|c|c|c|c|}
\hline & Labour & Capital & Output & Supply & Price & Rental \\
\hline Agric & 3.6900 & 3.6900 & 3.6900 & 3.6900 & -1.4700 & 0.5900 \\
\hline Mining & 1.5700 & 1.5800 & 1.5600 & 1.5700 & -1.6600 & 0.5900 \\
\hline FoodManu & 0.8700 & 0.8700 & 0.7300 & 0.7300 & 2.9600 & 0.5900 \\
\hline Textile & 1.9100 & 1.9100 & 1.9100 & 1.9100 & 2.1900 & 0.5900 \\
\hline SawMill & 1.9000 & 1.9000 & 1.9000 & 1.9000 & 0.9200 & 0.5900 \\
\hline Paper & -5.0500 & -5.0500 & -5.0500 & -5.0500 & -0.4000 & 0.5900 \\
\hline Rubber & 0.2000 & 0.2000 & 0.2000 & 0.2000 & 2.8400 & 0.5900 \\
\hline NonMetal & 0.6900 & 0.6900 & 0.6900 & 0.6900 & 0.3000 & 0.5900 \\
\hline Metal & 1.5400 & 1.5400 & 1.5400 & 1.5400 & -0.3000 & 0.5900 \\
\hline OthManu & -0.5300 & -0.5300 & -0.5300 & -0.5300 & 2.5000 & 0.5900 \\
\hline Const & -0.3100 & -0.3100 & -0.3100 & -0.3100 & -0.6000 & 0.5900 \\
\hline Trade & -2.5200 & -2.5200 & -2.5200 & -2.5200 & -1.0800 & 0.5900 \\
\hline Trans & 1.6000 & 1.6000 & 1.6000 & 1.6000 & 1.0200 & 0.5900 \\
\hline Coal & 0.2400 & 0.2500 & 0.2400 & 0.2500 & 0.5100 & 0.5900 \\
\hline Petro & 2.0000 & 2.0000 & 2.0000 & 2.0000 & 1.3400 & 0.5900 \\
\hline PetroRefin & 4.7200 & 4.7200 & 4.9400 & 4.9400 & -5.1700 & 0.5900 \\
\hline OthPetro & 1.3000 & 1.3000 & 1.3000 & 1.3000 & 0.3000 & 0.5900 \\
\hline Electri & 0.6500 & 0.6500 & 0.6500 & 0.6500 & -0.6000 & 0.5900 \\
\hline
\end{tabular}

Source: Own calculations for the CGE model of Thailand using data from the National Economics and Social Development Board (2016)

Consequently, output, supply, capital and labour in these sectors increased. On the other hand, the rise in prices in the other manufacturing and unclassified sector resulted in a decrease in output, capital and employment of $0.53 \%$. Furthermore, this policy not only increased the price in the food manufacturing sector, textile industry, saw mills and wood products, rubber and chemical industries, non-metallic products, and transportation and communication sector, but also increased employment, capital and output in these sectors. For the remaining sectors, this policy led to a reduction in prices, employment, capitas and output.

In the energy sector, the petroleum refineries sector had the biggest increases in employment, capital and output, followed by the petroleum and natural gas sector, other petroleum product sector, electricity sector, and coal and lignite sector. Moreover, this policy benefited the producers in the petroleum and natural gas sector, coal and lignite sector, and other petroleum product sector as it increased the prices of these products. On the contrary, this policy favoured the consumers in the sense that it lowered the prices in the petroleum refineries and electricity product sectors by 5.17 and $0.6 \%$, respectively.

The rental rate in the $0 \%$ VAT case increased by $0.59 \%$ in all sectors as the price of capital in this study was assumed to be equal in all sectors. The simulation result in the 
Table 5 Percentage Change in Macroeconomic Variables of Decreasing in CIT from 30 to 23 Percent

\begin{tabular}{|c|c|c|c|c|c|c|}
\hline & Labour & Capital & Output & Supply & Price & Rental \\
\hline Agric & 2.5100 & 2.6600 & 2.5800 & 2.5800 & 0.0900 & 0.0000 \\
\hline Mining & 3.2600 & 3.4000 & 3.3300 & 3.3300 & 0.0900 & 0.0000 \\
\hline FoodManu & 1.6500 & 1.7900 & 1.5800 & 1.5800 & 1.9000 & 0.0000 \\
\hline Textile & 4.9800 & 5.1300 & 5.0500 & 5.0500 & 0.0000 & 0.0000 \\
\hline SawMill & 2.2500 & 2.4000 & 2.3100 & 2.3100 & 0.0000 & 0.0000 \\
\hline Paper & -2.7400 & -2.6000 & -2.6900 & -2.6900 & 0.1000 & 0.0000 \\
\hline Rubber & 1.5900 & 1.7300 & 1.6600 & 1.6600 & 0.1100 & 0.0000 \\
\hline NonMetal & 0.4100 & 0.5500 & 0.4700 & 0.4700 & 0.0000 & 0.0000 \\
\hline Metal & -1.8200 & -1.6800 & -1.7800 & 0.0000 & 0.0000 & 0.0000 \\
\hline OthManu & 2.5800 & 2.7200 & 2.6500 & 2.6500 & 0.1100 & 0.0000 \\
\hline Const & -0.2700 & -0.1300 & -0.2100 & -0.2100 & 0.0900 & 0.0000 \\
\hline Trade & -2.0300 & -1.8900 & -1.9800 & -1.9800 & 0.0900 & 0.0000 \\
\hline Trans & 2.0700 & 2.2200 & 2.1500 & 2.1500 & 0.1000 & 0.0000 \\
\hline Coal & -0.2200 & -0.0800 & -0.1700 & -0.1600 & 0.0000 & 0.0000 \\
\hline Petro & 1.6600 & 1.8000 & 1.7100 & 1.7100 & 0.1000 & 0.0000 \\
\hline PetroRefin & 1.0600 & 1.2000 & 1.1200 & 1.1200 & 0.0800 & 0.0000 \\
\hline OthPetro & 1.3100 & 1.4500 & 1.3600 & 1.3600 & 0.0000 & 0.0000 \\
\hline Electri & 0.1400 & 0.2800 & 0.2000 & 0.2000 & 0.0000 & 0.0000 \\
\hline
\end{tabular}

Source: Own calculations for the CGE model of Thailand using data from the National Economics and Social Development Board (2016)

benchmark case when the CIT rate equaled 30\% showed similar results to the benchmark case of the 7\% VAT rate explained earlier (Online Supplemental Appendix Table 4).

In comparison, decreasing the CIT rate from 30 to $23 \%$ reduced employment, capital, output and supply in the paper industries and printing sector, metal, metal products and machinery sector, construction sector, trade and services sectors and also in the coal and lignite sectors. At the same time, this policy boosted the use of factors and outputs in many important sectors in Thailand, such as the agriculture sector, rubber and chemical industries, textile industry, and other manufacturing and unclassified sector. The income effect was greater than the substitution effect in this case as demand increased due to tax rebates which resulted in an increase in the prices in all sectors, particularly, in the food manufacturing sector which increased in price by $1.9 \%$ (Table 5). Consistent with the Thai economy in 2010, the prices of commodities products excluding fuel rose by $21.4 \%$ on a yearly average basis and the Thai economy expanded by $7.8 \%$ (Bank of Thailand 2011).

The results of reducing the CIT rate from 30 to $20 \%$ were similar to lowering the CIT rate to $23 \%$. However, the magnitude of changes in every sector was different. For instance, output in the food manufacturing sector increased by $1.58 \%$ when the CIT rate was $23 \%$ and increased to $3.45 \%$ when the CIT rate is $20 \%$. Furthermore, a remarkable 
Table 6 Welfare Analysis: Utility from Private and Public Goods and Net-Gains

\begin{tabular}{lccccc}
\hline & $\begin{array}{l}\text { Household } \\
\text { utility }\end{array}$ & Change in utility (\%) & Public utility & $\begin{array}{l}\text { Change in public } \\
\text { utility (\%) }\end{array}$ & Net gain $^{1}(\%)$ \\
\hline VAT 7\% & 2.734 & & 0.562 & & \\
VAT 10\% & 2.648 & -3.146 & 0.802 & 42.705 & 6.941 \\
VAT 0\% & 2.920 & 6.803 & 0.043 & -92.349 & -15.010 \\
CIT 30\% & 4.999 & & 2.204 & & \\
CIT 23\% & 5.261 & 5.241 & 1.910 & -13.339 & 1.153 \\
CIT 20\% & 5.400 & 8.022 & 1.757 & -20.281 & 1.795 \\
\hline
\end{tabular}

${ }^{1}$ In 2010, government expenditure accounted for $22.02 \%$ of GDP. So government weight is 0.22 while private weight is 0.78 . Net gain $=0.78(-3.146)+0.22(42.705)=6.941$.

change occurred in the metal, metal products and machinery industry. Supply and price in this sector decreased after the CIT rate change to $20 \%$ compared to the benchmark case. This policy also decreased prices in the transportation and communication sector, petroleum refineries sector, and electricity sectors (Online Supplemental Appendix 5).

Under a non-balanced budget, Amir et al. (2013) found that a decrease in the Indonesian CIT rate caused a reduction in output in some sectors, while the prices in all sectors increased. For balanced budgets, they reported that all outputs increased while all prices decreased. In contrast with similar CIT reduction under the balanced budget scenario in this model, output increased in 13 sectors and marginally decreased in five sectors, with almost no effect on the prices of products.

In addition, our CGE model explains the change in the utility level of households and public welfare (Table 6). An increase in the VAT rate reduced Household utility by $3.146 \%$ and increased public welfare by $42.705 \%$. Weighting welfare by the respective sizes of the private and public sectors $(0.78 \%$ and $0.22 \%)$, the net welfare gain was $6.941 \%$. This means the public sector can compensate private losses through public services or transfers to households.

On the other hand, removing the VAT accelerated household utility by $6.803 \%$ but reduced public welfare by $92.349 \%$. Consequently, the net loss to social welfare was $15.010 \%$. Therefore, aggregate changes in the net welfare effect of a 10\% VAT rate are better than a $0 \%$ VAT rate because utility from public services for households more than compensates their loss of utility due to the higher tax rate. Therefore, increasing VAT from 7 to $10 \%$ becomes a desirable policy action on the basis of economy-wide welfare analysis.

Moreover, the welfare impact of a change in the CIT rate indicates that a decrease in the CIT rate from 30 to $23 \%$ not only led to an increase in household utility by $5.241 \%$ but also decreased public welfare by $13.339 \%$. In addition, the permanent CIT rate of $20 \%$ increased the household utility level by $8.002 \%$ but lessened public welfare by $20.281 \%$, compared to the benchmark case. Although the reduction of the CIT rate increased household welfare in both cases, the magnitude of the changes was less than the decrease in public welfare. Therefore, the increase in private utilities cannot compensate for the loss of public welfare due to a lower CIT rate. Accordingly, the net gain of $20 \%$ in the CIT rate was slightly higher 
than the $23 \%$ CIT rate. Thus, decreasing the CIT rate from 30 to $20 \%$ was the preferred policy tool as the overall change in net welfare effect of $20 \%$ was better than a $23 \%$ change.

While the above results based on the CGE model of the Thai economy were robust within the model structure, they were influenced by the model structure. On one hand, results from the comparative static analysis can best be said to represent the steady state behavior of the model economy. Full impact analysis requires a full-scale dynamic model. Though this model reflects heterogeneity of firms, it still focuses on only the representative household. As the impact of public policy is likely to differ by household, such models should include a multiplicity of households. Both assumptions will be relaxed for the analysis of growth and equity in our future work. The efficiency analysis presented here is, in itself, a unique contribution to the current literature on the impact of the VAT and CIT in the Thai economy.

\section{Conclusions}

A CGE model of the Thai economy was constructed by utilizing the micro-consistent data contained in the Input-Output Table 2010 published by the National Economics and Social Development Board (2016) with some restructuring into 18 sectors. This paper contributes to the existing literature by examining for the first time the economywide impact of changes in the VAT and CIT rate on the allocation of labour and capital inputs on output and supply as well as on prices and rental rates across sectors and on the levels of household utility and public welfare in Thailand.

Results reveal that an increase in the VAT rate from 7 to $10 \%$ generates an increase in public welfare with a decrease in household utility from the consumption of private goods. A higher VAT rate raises prices and lowers outputs in many sectors, especially in the agriculture and food manufacturing sectors. On the other hand, this policy has favorable effects for producers in some sectors, such as the mining and quarrying sector, and trade and services sectors, leading to increases in both output and prices. For the energy sector, output only increases in the other petroleum product sector, whereas prices rise in the petroleum refineries and electricity sectors.

The elimination of VAT boosts output in most sectors. However, the increase in household utility from private consumption cannot compensate enough for the reduction in utility from public consumption. Thus, the VAT can have a positive impact on welfare when revenues are used prudently for providing public services. In comparison, increasing the VAT rate from 7 to $10 \%$ becomes a desirable policy action on the basis of economy-wide welfare analysis because the utility from the public services for households more than compensates for their loss of utility due to higher tax rates.

For the reduction in the CIT rate, the findings are similar to the VAT results, but the magnitude of changes across sectors are different. Although these policies increase household welfare in both cases, the changes are less than the size of the decrease in public welfare. In comparison, decreasing the CIT rate from 30 to $20 \%$ is a more preferable policy as the overall net change in welfare of $20 \%$ in the CIT rate is better than a net change of $23 \%$.

Acknowledgements We appreciate comments from two anonymous referees of International Advances in Economic Research and participants of INFER 2017 in Bordeaux, France and the International Atlantic Economic Conference in Montreal, Canada, 5-8 October 2017, for their comments and suggestions. 
Open Access This article is distributed under the terms of the Creative Commons Attribution 4.0 International License (http://creativecommons.org/licenses/by/4.0/), which permits unrestricted use, distribution, and reproduction in any medium, provided you give appropriate credit to the original author(s) and the source, provide a link to the Creative Commons license, and indicate if changes were made.

\section{References}

Al-Amin, A.Q., Jaafar, A.H., and Siwar, C. (2008). A Computable General Equilibrium Approach to Trade and Environmental Modelling in the Malaysian Economy. MPRA Paper 8772 Available online: https://mpra.ub.uni-muenchen.de/8772/ Accessed 2 Aug 2017.

Amir, H., Asafu-Adjaye, J., \& Ducpham, T. (2013). The Impact of the Indonesian Income Tax Reform: A CGE Analysis. Economic Modelling, 31, 492-501.

Arnold, J. M., Brys, B., Heady, C., Johansson, A., Schwellnus, C., \& Vartia, L. (2011). Tax policy for economic recovery and growth. The Economic Journal, 121(505), F59-F80.

AvalaraVatlive. (2016). International VAT and GST rates 2016. Available online: http://www.vatlive.com/vatrates/international-vat-and-gst-rates Accessed 2 Aug 2017.

Bangkok Post. (2018). Cabinet keeps VAT at 7\% for another year. Internet Edition. 3 July. Available online: https://www.bangkokpost.com/news/general/1496806/cabinet-keeps-vat-at-7-for-another-year Accessed 9 Nov 2018.

Bank of Thailand. (2011). Thailand's economic condition in 2010. Available online: https://www.bot.or. th/English/MonetaryPolicy/EconomicConditions/AnnualReport/AnnualReport/AnnualReport_2010.pdf Accessed Nov 82017.

Barrell, R., \& Weale, M. (2009). The economics of a reduction in VAT. Fiscal Studies, 30(1), 17-30.

Bergman, L. (1990). Energy and environmental constraints on growth: A CGE modelling approach. Journal of Policy Modeling, 12(4), 671-691.

Bhattarai, K. (2007). Input-Output and General Equilibrium Models for Hull and Humber Region in England. Atlantic Economic Journal, 35(4), 473-490.

Bhattarai, K. (2008). Economic theory and models: Derivations, Computations and Applications for Policy Analyses (pp. 60-86). New Delhi: Serials Publications.

Bhattarai, K. (2011). General equilibrium impacts of energy and pollution taxes in UK. UK: University of Hull unpublished manuscript. Available online: https://www.qmul.ac.uk/busman $/ \mathrm{media} / \mathrm{sbm} / \mathrm{news}$ andevents/eventdocuments/CapGrEnv_JP.pdf Accessed 28 Mar 2016.

Bhattarai, K. (2016). Growth and income distributions in four EU economies. International Advances in Economic Research, 22(3), 263-277.

Bhattarai, K. (2017). Welfare and distributional impacts of financial liberalization in an Open Economy: Lessons from a Multi-Sectoral Dynamic CGE Model for Nepal. International Business Research, 10(1), 181-198.

Blundell, R. (2009). Assessing the temporary VAT cut policy in the UK. Fiscal Studies, 30(1), 31-38.

Dailynews. (2015). Reduce corporate income tax to $20 \%$ permanently. Dailynews, Internet edition. 13 October. Available online: https://www.dailynews.co.th/economic/354191 Accessed 8 Aug 2017.

Field, A. J., \& Wongwatanasin, U. (2007). Tax policies' impact on output, trade and income in Thailand. Journal of Policy Modeling, 29(3), 361-380.

Fiscal Information. (2016). Government revenue year 1992 to year 2016. Available online: http://dwfoc.mof. go.th/Dataservices/GovernmentRevenue?language=EN Accessed 21 Sept 2016.

GAMS Corporation. (2017). GAMS/MPSGE Manual. www.gams.com.

KPMG. (2017). Corporate tax rates table. Available online: https:/home.kpmg.com/xx/en/home/services/tax/taxtools-and-resources/tax-rates-online/corporate-tax-rates-table.html Accessed 5 Aug 2017.

Lee, Y., \& Gordon, R. H. (2005). Tax structure and economic growth. Journal of Public Economics, 89(5-6), 1027-1043.

McNabb, K., and LeMay-Boucher, P. (2014). Tax structures, economic growth and development. ICTD Working Paper, 22. Available online: https://papers.ssrn.com/sol3/papers.cfm?abstract_id=2496470 Accessed 10 Aug 2017.

Mok, C.Y. (2017). GST Implementation in Malaysia. Available online: http://www.bdo. ae/getattachment/Services/Tax/VAT/VAT-Presentations/BDO-Mok-Chew-Yin-_-GST-Implementation-inMalaysia-10-4-17-(Full).pdf.aspx?lang=en-GB Accessed 15 Nov 2017. 
National Economics and Social Development Board. (2016). Input-Output Table 2010. Available online: http://www.nesdb.go.th/nesdb_en/ewt_news.php?nid=4366\&filename=national_account Accessed 30 Mar 2016.

Onwuchekwa, J. C., \& Aruwa, S. A. (2014). Value added tax and economic growth in Nigeria. European Journal of Accounting Auditing and Finance Research, 2(8), 62-69.

Puttanapong, N., Wachirarangsrikul, S., Phonpho, W., \& Raksakulkarn, V. (2015). A Monte-Carlo Dynamic CGE Model for the Impact Analysis of Thailand's Carbon Tax Policies. Journal of Sustainable Energy \& Environment, 6, 43-53.

Revenue Department. (2018). Corporate Income Tax. Available online: http://www.rd.go.th/publish/6044.0. html Accessed 11 Sept 2018.

Ruamsuke, K., Dhakal, S., \& Marpaung, C. (2015). Energy and economic impacts of the global climate change policy on Southeast Asian countries: a general equilibrium analysis). Energy, 81, 446-461.

Semboja, H. H. H. (1994). The effects of energy taxes on the Kenyan economy: a CGE analysis. Energy Economics, 16(3), 205-215.

Sujjapongse, S. (2005). Tax policy and reform in Asian countries: Thailand's perspective. Journal of Asian Economics, 16(6), 1012-1028.

Wianwiwat, S., \& Asafu-Adjaye, J. (2013). Is there a role for biofuels in promoting energy self sufficiency and security? A CGE analysis of biofuel policy in Thailand. Energy Policy, 55, 543-555.

Winyuchakrit, P., Limmeechokchai, B., Matsuoka, Y., Gomi, K., Kainuma, M., Fujino, J., \& Suda, M. (2011). Thailand's low-carbon scenario 2030: Analyses of demand side CO 2 mitigation options. Energy for Sustainable Development, 15(4), 460-466.

Publisher's Note Springer Nature remains neutral with regard to jurisdictional claims in published maps and institutional affiliations. 